\title{
Integrative Gastroenterology and Hepatology The 9-bp Deletion at Position 8272 in Region V of Mitochondrial DNA is Associated with Outcome of Colorectal Cancer
}

\author{
Liu $\mathbf{Q}^{1 *}$, Xie $\mathbf{S}^{1}$, Jiao $\mathbf{P}^{1}$, Liu $\mathbf{G}^{1}$ and Guo $Z^{2}$ \\ 'Department of Thoracic Surgery, the Fourth Hospital of Hebei Medical University, Shijiazhuang, China \\ 2Departments of Gastroenterology and Hepatology, the Fourth Hospital of Hebei Medical University, Shijiazhuang,
}

China

*Correspondence: Qingyi Liu, Department of Thoracic Surgery, The Fourth Hospital of He bei Medical University, 12 subsequent analysis, Jiankang Road, Shijiazhuang 050011, PR China, Tel: 13831108025; Fax: 031186095352;

E-mail:18032168201@163.com

Received: Apr 03, 2019; Accepted: Apr 27, 2019; Published: May 02, 2019

\begin{abstract}
The 9-bp deletion of CCCCCTCTA at position 8272 in region $V$ of mitochondrial DNA is one of the mitochondrial DNA microsatellite instability (mtMSI) sites that associated with cancers. In the present study, we investigated the association of 8272 deletion with the cancer risk and outcome for colorectal cancer (CRC). By the log-rank analysis, the 8272 CCCCCTCTA/del was identified as a prognostic marker for outcome of colorectal cancer patients with the deleted ones associated with shorter postoperative survival. After adjusted with Cox Hazard model, this MSI was associated independently with CRC outcome (relative risk, $2.038 ; 95 \% \mathrm{Cl}, 1.20-3.707 ; p=0.020$ ). The analysis of mtMSI can help to identify patient subgroups that are at high risk for poor disease outcomes.
\end{abstract}

Keywords: 8272 , Mitochondrial DNA, mtMSI, Outcome, CRC

\section{Introduction}

Colorectal cancer (CRC) is the third most common cancer type amounted for about 7 hundred thousand deaths each year, which makes it the fourth leading cause of cancer-related mortality in both sexes worldwide. The evidence that the disease is significantly increasing in most developing countries heralds an even more remarkable disease burden in the near future [1]. Although the metastasis status, the expression of oncogene or tumor suppressor gene, and the microsatellite instability (MSI) analysis have been identified as prognostic markers in colorectal cancer patients $[2,3]$, but the mechanism of CRC development is unclear yet.

Mitochondrial DNA (mtDNA) is believed to be more susceptible to DNA damage and acquires mutations at a higher rate than nuclear DNA due to high levels of reactive oxygen species (ROS), a lack of protective histones and a limited capacity for DNA repair in the mitochondria [4,5]. Microsatellites are simple tandem repeats of short DNA motifs that are present at millions of loci in the human genome. Microsatellite instability (MSI) refers to DNA slippage events on microsatellites that occur frequently in cancer genomes particularly in CRC genomes [6,7]. Recently, MSIs in mitochondrial genome have been reported in a variety of cancers including colon cancer, sporadic cancer and lung cancer [8-10]. Moreover, mtMSIs have been selected for predicting cancer risk and outcome of CRC $[11,12]$. As one of mtMSI site, the 9-bp deletion at position 8272 in region $\mathrm{V}$ of mitochondrial DNA was identified as risk and outcome predictor for hepatocellular carcinoma and renal cancer $[13,14]$. In the present study, we evaluate the predictive value of this 
MSI site on cancer risk and outcome for CRC cancer.

\section{Materials and Methods}

\section{Tissue specimens and DNA extraction}

Blood samples were obtained from 130 CRC patients who received colorectal cancer resection at the Department of Surgery in the Fourth Hospital of Hebei Medical University between 2005 and 2008. Blood samples were also collected from 79 healthy controls. Total DNA was extracted using a Wizard Genomic DNA Extraction Kit (Promega, Madison, WI, USA) and stored at $-20^{\circ} \mathrm{C}$. The study was approved by the Human Tissue Research Committee of the Fourth Hospital of Hebei Medical University. All patients provided written informed consent for the collection of samples and subsequent analysis.

\section{PCR amplification and sequence analysis of 8272MSI}

The forward primer 5'-ACCACTTTCACCGCTACACG-3' and reverse prime 5'-TTTAGTTGGGGCATTTCACTG-3' were used to amplify DNA fragments flanking the 8272 MSI site (http://www.mitomap.org). Polymerase chain reactions (PCRs) were performed according to the PCR Master Mix Kit (Promega) protocol and purified prior to sequencing. The PCR condition consisted of an incubation for $2 \mathrm{~min}$ at $95^{\circ} \mathrm{C}$; followed by 35 cycles of denaturation for $30 \mathrm{~s}$ at $95^{\circ} \mathrm{C}$, annealing for $30 \mathrm{~s}$ at $55^{\circ} \mathrm{C}$, and extension for 45 $\mathrm{S}$ at $72^{\circ} \mathrm{C}$; and a final extension for $5 \mathrm{~min}$ at $72^{\circ} \mathrm{C}$. Cycle sequencing was performed with the Dye Terminator Cycle Sequencing Ready Reaction Kit (Applied Biosystem, Foster (ity, CA, USA) to detect the deletion, and the products were then separated on an ABIPRISM Genetic Analyzer 3100 (Applied Biosystem). MSI sequences were confirmed by repeated analyses from both strands.

\section{Statistical analysis}

The $\chi^{2}$ test was used to analyze dichotomous values, such as the presence or absence of the 9bp deletion in CRC patients and healthy controls. The survival curve was calculated using the Kapla-Meier method and compared using the log-rank test. Multivariate survival analysis was performed using the Cox proportional hazards model. All statistical analyses were performed using SPSS17.0 software (SPSS Company, Chicago, IL, USA). For all statistical tests, $p<0.05$ was considered significantly different.

\section{Results}

\section{Clinical characteristics of CRC patients}

A total of 130 CRC patients were enrolled in this study. A review was conducted every six months over a five-year period. The clinical characteristics of the CRC patients are listed in table 1. We assessed the distribution frequency between CRC patients and control, but no statistically significant differences were found.

We analyzed the association between patients' clinical characteristics and postoperative survival time for CRC patients by log-rank test using the Kaplan-Meier method. The TNM stage, metastasis status and preoperative chemotheraphy were identified for their association with 5 years survival rate.

Table 1: Univariate analysis of clinical characteristics associated with postoperative survival in CRC patients.

\begin{tabular}{|c|c|c|c|}
\hline Characteristics & $\begin{array}{l}\text { No. } \\
\text { cases }\end{array}$ & $\begin{array}{l}5 \text { years } \\
\text { survival } \\
\text { rate }(\%)\end{array}$ & P value \\
\hline Gender & & & 0.39 \\
\hline $\begin{array}{l}\text { Male } \\
\text { Female }\end{array}$ & $\begin{array}{l}78 \\
52\end{array}$ & $\begin{array}{l}53.8 \\
59.6\end{array}$ & \\
\hline Age (years) & & & 0.754 \\
\hline $\begin{array}{l}\leq 60 \\
>60\end{array}$ & $\begin{array}{l}64 \\
66\end{array}$ & $\begin{array}{l}57.8 \\
54.5\end{array}$ & \\
\hline Tumor size (diameter) & & & 0.806 \\
\hline $\begin{array}{l}\leq 5 \mathrm{~cm} \\
>5 \mathrm{~cm}\end{array}$ & $\begin{array}{l}60 \\
70\end{array}$ & $\begin{array}{l}56.7 \\
55.7\end{array}$ & \\
\hline Lymph node metastasis & & & 0.002 \\
\hline $\begin{array}{l}\text { N0 } \\
\text { N1 } \\
\text { N2 }\end{array}$ & $\begin{array}{l}81 \\
36 \\
13\end{array}$ & $\begin{array}{l}66.7 \\
41.7 \\
30.8 \\
\end{array}$ & \\
\hline Subsite & & & 0.361 \\
\hline $\begin{array}{l}\text { Right colon } \\
\text { Middle colon } \\
\text { Left colon } \\
\text { Rectum }\end{array}$ & $\begin{array}{l}60 \\
7 \\
60 \\
3\end{array}$ & $\begin{array}{l}55 \\
87.5 \\
54.2 \\
33.3\end{array}$ & \\
\hline TNM stages & & & 0.000 \\
\hline $\begin{array}{l}\mathrm{I}+\mathrm{II} \\
\mathrm{III}+\mathrm{IV}\end{array}$ & $\begin{array}{l}66 \\
64\end{array}$ & $\begin{array}{l}78.8 \\
32.8\end{array}$ & \\
\hline $\begin{array}{l}\text { Postoperative chemo- } \\
\text { therapy }\end{array}$ & & & 0.026 \\
\hline $\begin{array}{l}\text { Yes } \\
\text { No }\end{array}$ & $\begin{array}{l}7 \\
123\end{array}$ & $\begin{array}{l}28.6 \\
57.7\end{array}$ & \\
\hline $\begin{array}{l}\text { Widetype } \\
\text { 9-bp deletion }\end{array}$ & $\begin{array}{l}109 \\
21\end{array}$ & $\begin{array}{l}61.5 \\
28.6\end{array}$ & 0.003 \\
\hline
\end{tabular}




\section{The association of 8272 MSI with CRC survival}

The 8272 CCCCCTCTA/del was genotyped in CRC patients, and their association with postoparative was calculated by log-rank test with Klpan-Meier method. As shown in figure 1, the CRC patient's caring 9-bp deletion genotype display shorter postoperative survival. After adjusted with the Cox hazard model by the multivariate analysis, the $8272 \mathrm{MSI}$ site was identified as an independent predictor for CRC survival (relative risk, $2.038 ; 95 \% \mathrm{Cl}, 1.20-3.707 ; p=0.020$ ), as shown in table 2 .

Table 2: Multivariate analysis of prognostic factors associated with postoperaive survival in CRC patients with COX proportional hazards model.

\begin{tabular}{l|l|l|l}
\hline \multicolumn{1}{c|}{ Factors } & \multicolumn{1}{c|}{ OR } & \multicolumn{1}{c|}{$\mathbf{9 5 \%} \mathbf{C l}$} & P value \\
\hline 9-bp deletion & 2.038 & $1.120 \sim 3.707$ & 0.02 \\
\hline $\begin{array}{l}\text { Lymph node } \\
\text { metastasis }\end{array}$ & 0.789 & $0.459 \sim 1.358$ & 0.393 \\
\hline TNM stages & 5.547 & $2.522 \sim 12.200$ & 0.001 \\
\hline $\begin{array}{l}\text { Postoperative } \\
\text { chemotherapy }\end{array}$ & 2.161 & $0.857 \sim 5.449$ & 0.103 \\
\hline
\end{tabular}

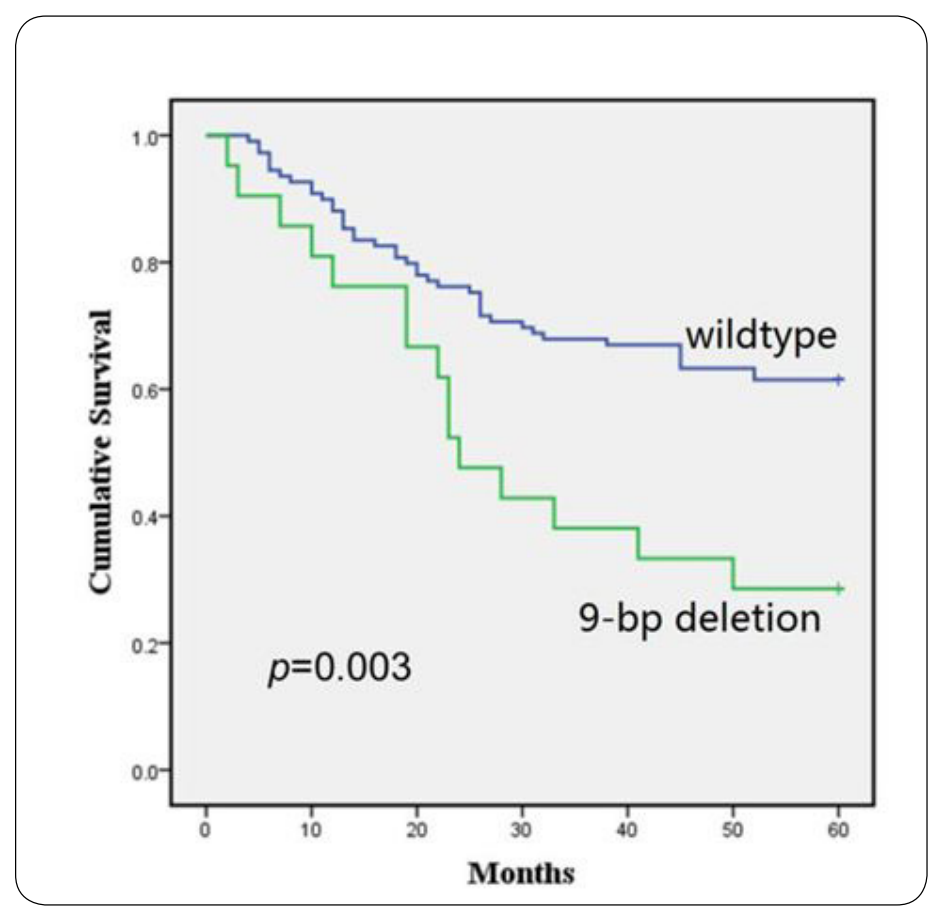

Figure 1: Survival curve of CRC patients based on genotype of $8272 \mathrm{MSI}$ of mitochondrial DNA.

\section{Discussion}

Mitochondrial MSI had been identified as a prognostic marker in many types of cancer, including colon cancer, sporadic cancer, and lung cancer [8-10]. We prolonged this study and found one of the mtMSI, the 8272CCCCCTCTA/ del was associated independently with CRC outcome. To Int Gast Hepatol, 2(1): 155-158 (2019) our knowledge, this is the first report that $8272 \mathrm{MSI}$ is associated with the CRC outcome.

Mitochondrial DNA variation may affect the efficiency of the mitochondrial electron transport chain to generate excessive ROS, which contribute to the development of cancers $[15,16] .8272$ CCCCCTCTA/del is located in the intergenic mtDNA region $V$ where hsa-miR-519c-5p binding, the deletion of 8272 CCCCCTCTA destroys the binding affinity between hsa-miR-519c-5p and mtDNA thereby to alter downstream and/or upstream genes expression. The crucial component of the respiratory chain including ATP synthase 8 (MT-ATP8), ATP synthase 6 (MTATP6), cytochrome oxidase III (MT-CO3), and cytochrome b (MT-CYB) are all located downstream of 8272 site. The abnormal expression of these genes can alter the status of oxidative phosphorylation and oxidative stress so as to influence outcome of cancer $[17,18]$.

\section{Conclusion}

In conclusion, an mtDNA MSI at 8272 site was found to be an independent prognostic marker for CRC outcomes. The analysis of mtMSIs can help to identify patient subgroups with poor prognoses and may, accordingly, help to refine therapeutic decisions in patients with CRC

\section{Acknowledgements}

Not applicable

\section{Funding}

This work was supported by the Hebei Medical Science major project (GL2012054)

\section{Availability of data and materials}

The datasets used and/or analyzed during the present study are available from the corresponding author on reasonable request.

\section{Authors' contributions}

In the study, QL collected the data and wrote the manuscript. SX is in charge of DNA extraction and subsequent analysis. PJ collected the blood samples.GL is in charge of date review and Statistical analysis. ZG contributed to project design and manuscript review.

\section{Ethics approval and consent to participate}

All procedures were supervised and approved by the Ethics Committee of The Fourth Hospital of Hebei Medical University. 


\section{Patient consent for publication}

The patient provided written informed consent prior to enrolment in the study.

\section{Declaration of interest}

All of the authors declare that financial, consulting and personal relationships with other people or organizations did not influence this work.

\section{References}

1. Sung JJY, Lau JYW, Goh KL, Leung WK, Asia Pacific Working Group on Colorectal Cancer. Increasing incidence of colorectal cancer in Asia: implications for screening. Lancet Oncol. 2005;6(11):871-876. Doi: http://dx.doi.org/10.1016/S1470-2045(05)70422-8

2. Reimers MS, Zeestraten ECM, Kuppen PJK, Liefers $\mathrm{GJ}$, van de Velde $\mathrm{CJH}$. Biomarkers in precision therapy in colorectal cancer. Gastroenterol Rep (Oxf). 2013;1(3):166-183. Doi: http://dx.doi.org/10.1093/ gastro/got022

3. Isik A, Peker K, Firat D, et al. Importance of metastatic lymph node ratio in non-metastatic, lymph nodeinvaded colon cancer: a clinical trial. Med Sci Monit. 2014;20:1369-1375. Doi: http://dx.doi.org/10.12659/ MSM.890804

4. Taylor RW, Turnbull DM. Mitochondrial DNA mutations in human disease. Nat Rev Genet. 2005;6(5):389-402. Doi: http://dx.doi.org/10.1038/nrg1606

5. Beal MF. Mitochondria, free radicals, and neurodegeneration. Curr Opin Neurobiol. 1996;6(5):661-666. https://www.ncbi.nlm.nih.gov/ pubmed/8937831

6. Kim T-M, Park PJ. A genome-wide view of microsatellite instability: old stories of cancer mutations revisited with new sequencing technologies. Cancer Res. 2014;74(22):6377-6382. Doi: http://dx.doi. org/10.1158/0008-5472.CAN-14-1225

7. Söreide $K$, Janssen E a. M, Söiland H, Körner H, Baak JPA. Microsatellite instability in colorectal cancer. Br J Surg. 2006;93(4):395-406. Doi: http://dx.doi. org/10.1002/bjs.5328

8. Sinicrope FA, Sargent DJ. Clinical implications of microsatellite instability in sporadic colon cancers. Curr Opin Oncol. 2009;21(4):369-373. Doi: http:// dx.doi.org/10.1097/CCO.0b013e32832c94bd

9. Dai J-G, Zhang Z-Y, Liu Q-X, Min J-X. Mitochondrial genome microsatellite instability and copy number alteration in lung carcinomas. Asian Pac J Cancer Prev. 2013;14(4):2393-2399. https://www.ncbi.nlm.nih.gov/ pubmed/23725147

10. Lawes DA, SenGupta S, Boulos PB. The clinical importance and prognostic implications of microsatellite instability in sporadic cancer. Eur J Surg Oncol. 2003;29(3):201-212. https://www.ncbi.nlm.nih. gov/pubmed/12657227

11. Boland CR, GoelA. Microsatellite instability in colorectal cancer. Gastroenterology. 2010;138(6):2073-2087.e3. Doi: http://dx.doi.org/10.1053/j.gastro.2009.12.064

12. Guastadisegni C, Colafranceschi M, Ottini L, Dogliotti E. Microsatellite instability as a marker of prognosis and response to therapy: a metaanalysis of colorectal cancer survival data. Eur J Cancer. 2010;46(15):2788-2798. Doi: http://dx.doi. org/10.1016/j.ejca.2010.05.009

13. Jin $Y, Y u Q$, Zhou $D$, et al. The Mitochondrial DNA 9-bp Deletion polymorphism is a risk factor for hepatocellular carcinoma in the chinese population. Genet Test Mol Biomarkers. 2012;16(5):330-334. Doi: http://dx.doi.org/10.1089/gtmb.2011.0208

14. Bai Y, Guo Z, Xu J, et al. The 9-bp deletion at position 8272 in region $V$ of mitochondrial DNA is associated with renal cell carcinoma outcome. Mitochondrial DNA Part A. 2016;27(3):1973-1975. Doi: http://dx.doi.org/1 0.3109/19401736.2014.971312

15. Ding C, Li R, Wang P, Jin P, Li S, Guo Z. Identification of sequence polymorphisms in the D-loop region of mitochondrial DNA as a risk factor for lung cancer. Mitochondrial DNA. 2012;23(4):251-254. Doi: http:// dx.doi.org/10.3109/19401736.2012.674120

16. Cheng M, Guo Z, Li H, Li Z, Li C, Geng C. Identification of sequence polymorphisms in the mitochondrial displacement loop as risk factors for sporadic and familial breast cancer. Tumour Biol. 2014;35(5):47734777. Doi: http://dx.doi.org/10.1007/s13277-0141626-5

17. Pirinççi N, Kaba M, Geçit I, et al. Serum prolidase activity, oxidative stress, and antioxidant enzyme levels in patients with renal cell carcinoma. Toxicol Ind Health. 2016;32(2):193-199. Doi: http://dx.doi. org/10.1177/0748233713498924

18. Drewniak T, Wajdowicz A, Kwiatek W, Juszczak K, Maciukiewicz P. [Selected markers of oxidative stress and carcinogenic trace elements concentrations in the renal cell carcinoma tissue]. Pol Merkur Lekarski. 2012;32(192):378-381. https://www.ncbi.nlm.nih. gov/m/pubmed/22891563/ 